\title{
The Differences in Morphological Structure of Handball Player's from Junior League in Kosovo
}

\author{
Admire Hasani-Toverlani ${ }^{1}$, Vullnet Ameti ${ }^{1}$, Shpresa Memishi ${ }^{1}$ \\ 'University of Tetova, Faculty of Physical Education, Tetovo, Macedonia
}

\begin{abstract}
The aim of this study was to recognize the differences in the morphological structure of handball players from junior leagues in Kosovo. The sample included 20 male active handball players from four handball junior teams. They compete in irregular competition in Handball Federation, Kosovo, divided into 4 subsamples: five players were from H.C." Trepca" - Mitrovica, five players were from H.C. "Kastrioti" - Ferizaj, five players were from H.C. "Bashkim Idrizi"- Gjakova, and five players were from H.C."Prishtina"- Prishtina. Anthropometric characteristics were evaluated by a battery of five variables: body weight, body height, length of arms, length of hands and breadth of hand. The data were analyzed by a statistical package, they are processed in the SPPS program, version 20.0 forWindows. Scientific research is done in the composition of the anthropometric space. The standard central and dispersive parameters are calculated for all variables. The significance of the differences between the group was determined by a t-test for independent samples, at the significance level of $p<0.05$. Based on the results of this study, a significant difference was confirmed between anthropometric variables between most groups. These facts show that there are differences from the first-place team to the fourth place team in the Kosovo junior championship.
\end{abstract}

Key words: Handball, Junior League, Anthropometric Space, Kosovo

\section{Introduction}

Handball is a part of a sport collective game which is specific and has too much characteristic movement, like coordination and speed, when we need force, resistance and high precision. Like in every sport, if we want to have considerable success and result, the main goal of every handball player and professional collaborator in this field should be to train hard and with contemporary methods (Selimi, 2001; Srhoj, Marinovic, \& Rogulj, 2002; Ghobadi, Rajabi, Farzad, Bayati, \& Jeffreys, 2013; Alaj et al., 2015; Hoppe, Brochhagen, Baumgart, Bauer, \& Juergen, 2017). In scientific literature, it is known that for playing handball many complex anthropological characteristics, intensity, agility, explosive strength and speed are needed to have, which are essential in performing many motoric structures. Similar researches in this field of handball were done by the author (Koca, 2009; Vuleta, Milanovic, Grujic, \& Jaksic 2006; Arifi, Bjelica, \& Masanovic, 2019). When choosing a sport discipline, body constitution plays a significant role
(Bjelica \& Fratric, 2011). All competitive sports practiced at a higher level require that the body performs at the optimal biomechanical and physiological capacity (Saavedra et al., 2018). Logically, a junior handball player competing in the strongest leagues in his age group is expected to have the optimal physical requirements of the sport in question (Masanovic, 2018). Morphological characteristics are of great importance when it comes to orientation and selection in all sports disciplines, since they are present in the equation of the specification of almost every sport (Gjonbalaj, Georgiev, \& Bjelica, 2018). The anthropometric characteristics of the junior handball body can directly affect the positions they play, as well as the high skills of physical preparation, speed, durability, and so on. Anthropometric body characteristics affect the development of tactical and technical skills, the performance of each handball player, as well as anthropometric parameters, which are of particular importance in identifying and selecting talented players for handball sports (Ghobadi, et.al 2013; Srhoj et al.,

\section{Montenegro}

Spart

\section{A. Hasani-Toverlani}

The University of Tetova, Faculty of Physical Education, Ilinden nn, 1200 Tetova, Republic of North Macedonia

E-mail: admire.hasani@yahoo.com 
2002). It is very important to identify the differences between the variables in the anthropometric space of players who compete in the same rank in the Kosovo Handball Championship, and establish whether the differences are related to quality.

The aim of this research was to evaluate the morphological structure of the handball players from Kosovo, and to evaluate the morphological structure of players from each team separately, and to analyze the differences in some morphological characteristics among junior handball players, players of H.C. "Trepça" - Mitrovica, H.C. "Kastrioti” - Ferizaj, H.C. "Bashkim Idrizi" Gjakova and H.C. "Prishtina" - Prishtina., who compete in the Kosovo Handball Championship.

\section{Material \& Method}

In this research was included 20 male handball player of $18.25 \pm 0.54$ years old, active players from four handball junior teams which compete in a regular competition in Handball Federation, Kosovo. Sample is divided into 4 subsamples: five players were from H.C. "Trepça” - Mitrovica $(18.3 \pm 0.43)$, five players were from H.C. "Kastrioti” - Ferizaj (18.1 \pm 0.58$)$, five players were from H.C. "Bashkim Idrizi” - Gjakova (18.4 \pm 0.70$)$, and five players were from H.C. "Prishtina" - Prishtina (18.2 \pm 0.58$)$. All of them were from the left and right back position in the field.

In this research battery of five anthropometric variables are applied: body weight, body height, length of arms, length of hand, and breadth of hand. These measurements are made indoor, in the place where they train and in the morning time. Measurements are realized by a professional team, respecting rules of International Scientific of Advanced Kinanthropometric (ISAK) form (Marfell-Jones, Olds, Stewart, \& Carter, 2006). The players were measured with the following measuring instruments: anthropometer according to Martin with an accuracy of $0.1 \mathrm{~cm}$ - for length of arms, length of hand and breadth of hand; decimal scale - body weight accurate to within $0.1 \mathrm{~kg}$.

The data were analyzed by the statistical package SPPS, version 20.0 for Windows. The standard central and dispersive parameters are calculated for all variables. The significance of the differences between the group was determined by a t-test for independent samples, at the significance level of $\mathrm{p}<0.05$.

\section{Results}

Table 1 shows the basic descriptive statistical parameters of the anthropometric variables for all junior handball teams, which competed in Handball Championship League in the Republic of Kosovo (the teams are Trepca, Kastrioti, Prishtina, and Bashkim Idrizi).

Based on the central and dispersive parameters, and the values of the skewness and kurtosis, it can be noted that all variables are within the normal distribution boundaries. It can be seen from the value of the skewness that the variables of body weight, length of hand and breadth of hand have mild asymmetry for the weaker results because they have a positive sign; while the variables of body height and length of arms have a negative sign which indicates that the results reside right from the value of the arithmetic mean, i.e. among the higher values. By the value of the kurtosis, it can be seen that the all variables show that the distribution is flatter than normal, that is, there are more results accumulated in the tails of distribution.

Tabela 1. Basic statistical indicators in anthropometric space in handball players' measurements

\begin{tabular}{lcccccc}
\hline Variables & N & Min. & Max. & Mean \pm SD & Skew. & Kurt. \\
\hline Body Weight & 20 & 61.54 & 91.53 & $75.51 \pm 8.04$ & .374 & -.051 \\
Body Height & 20 & 172.73 & 196.34 & $184.55 \pm 6.36$ & -.150 & -.306 \\
Length of Arms & 20 & 77.23 & 85.46 & $81.35 \pm 2.58$ & -.228 & -1.144 \\
Lenght of Hand & 20 & 19.45 & 23.82 & $20.85 \pm 1.24$ & .767 & -.221 \\
Breadth of Hand & 20 & 20.31 & 25.44 & $22.35 \pm 1.42$ & .386 & -.260 \\
\hline
\end{tabular}

Note: $\mathrm{N}$ - number of number of respondents; Min - minimum value; Max - maximum value; Mean - arithmetic mean, SD - standard deviation; Skew. - Measure of asymmetry; Kurtosis - Measure of flattening

Based on the results presented in Table 2 we can find out valuable statistic difference in anthropometric and motoric space between the two groups, H.C „Kastrioti” and H.C
"Trepça”, valuable changes are presented in two anthropometric variables in favor of H.C "Trepça” from Mitrovica: length of hand and breadth of hand.

Tabela 2. A T-test between the two groups which are tested in anthropometric spaces

\begin{tabular}{lcccc}
\hline Variables & Group & N & Mean \pm SD & Sig. \\
\hline \multirow{2}{*}{ Body Weight } & Kastrioti & 5 & $73.91 \pm 3.53$ & \\
& Trepca & 5 & $80.91 \pm 9.19$ & .171 \\
Body Height & Kastrioti & 5 & $182.83 \pm 7.85$ & \\
& Trepca & 5 & $187.94 \pm 5.13$ & .264 \\
Length of Arms & Kastrioti & 5 & $80.21 \pm 2.25$ & .284 \\
& Trepca & 5 & $82.16 \pm 3.02$ & \\
Lenght of Hand & Kastrioti & 5 & $20.00 \pm .40$ & \multirow{2}{*}{$.048 *$} \\
& Trepca & 5 & $21.64 \pm 1.32$ & \\
Breadth of Hand & Kastrioti & 5 & $20.96 \pm .68$ & \multirow{2}{*}{$.009 *$} \\
\hline
\end{tabular}

Note: $\mathrm{N}$ - number of number of respondents; Sig. - significance level; * - significant difference between groups 
In Table 3 are presented the differences between H.C "Kastrioti" and the H.C "Prishtina" on the anthropometric

spaces are presented, and do not show that we have significant differences between these two groups.

Tabela 3. A T-test between the two groups which are tested in anthropometric spaces

\begin{tabular}{lcccc}
\hline Variables & Group & N & Mean \pm SD & Sig. \\
\hline \multirow{2}{*}{ Body Weight } & Kastrioti & 5 & $73.91 \pm 3.53$ & \multirow{2}{*}{.185 } \\
& Pristina & 5 & $68.89 \pm 6.62$ & \\
Body Height & Kastrioti & 5 & $182.83 \pm 7.85$ & .276 \\
Length of Arms & Pristina & 5 & $187.73 \pm 4.83$ & \\
& Kastrioti & 5 & $80.21 \pm 2.25$ & .153 \\
Lenght of Hand & Pristina & 5 & $82.31 \pm 1.92$ & \\
& Kastrioti & 5 & $20.00 \pm .40$ & .130 \\
Breadth of Hand & Pristina & 5 & $21.15 \pm 1.35$ & \\
& Kastrioti & 5 & $20.96 \pm .68$ & .125 \\
\hline
\end{tabular}

Table 4 presents the results between H.C "Kastrioti" and sented for breadth of hand in favor of H.C "Bashkim Idrizi". H.C "Bashkim Idrizi”, and significant differences are pre-

Tabela 4. A T-test between the two groups which are tested in anthropometric spaces

\begin{tabular}{lcccc}
\hline Variables & Group & N & Mean \pm SD & Sig. \\
\hline \multirow{2}{*}{ Body Weight } & Kastrioti & 5 & $73.91 \pm 3.53$ & \multirow{2}{*}{.302 } \\
Body Height & B. Idrizi & 5 & $38.31 \pm 7.89$ & \\
& Kastrioti & 5 & $182.83 \pm 7.85$ & \multirow{2}{*}{. } \\
Length of Arms & B. Idrizi & 5 & $179.72 \pm 4.61$ & \\
& Kastrioti & 5 & $80.21 \pm 2.25$ & .779 \\
Lenght of Hand & B. Idrizi & 5 & $80.71 \pm 3.12$ & \\
& Kastrioti & 5 & $20.00 \pm .40$ & \multirow{2}{*}{369} \\
Breadth of Hand & B. Idrizi & 5 & $20.60 \pm 1.30$ & \\
& Kastrioti & 5 & $20.96 \pm .68$ & $.010 *$ \\
\hline
\end{tabular}

In table 5 the results between H.C "Trepca" and H.C gnificant differences in variable body weight in favor of H.C "Prishtina" are presented. On this occasion are gained si- "Trepca".

Tabela 5. A T-test between the two groups which are tested in anthropometric spaces

\begin{tabular}{lcccc}
\hline Variables & Group & N & Mean \pm SD & Sig. \\
\hline \multirow{2}{*}{ Body Weight } & Trepca & 5 & $80.91 \pm 9.19$ & \multirow{2}{*}{$.048^{*}$} \\
& Pristina & 5 & $68.89 \pm 6.62$ & \\
Body Height & Trepca & 5 & $187.94 \pm 5.13$ & .948 \\
& Pristina & 5 & $187.73 \pm 4.83$ & \\
Length of Arms & Trepca & 5 & $82.16 \pm 3.02$ & .929 \\
& Pristina & 5 & $82.31 \pm 1.92$ & \\
Lenght of Hand & Trepca & 5 & $21.64 \pm 1.32$ & \\
& Pristina & 5 & $21.16 \pm 1.35$ & .587 \\
Breadth of Hand & Trepca & 5 & $23.03 \pm 1.06$ & .726 \\
& Pristina & 5 & $22.66 \pm 1.94$ & \\
\hline
\end{tabular}

In Table 6 the results are given between H.C "Trepça” and ted in favor of H.C "Trepça" to the body height. H.C "Bashkim Idrizi”, where significant differences are presen- 
Tabela 6. A T-test between the two groups which are tested in anthropometric spaces

\begin{tabular}{llccc}
\hline Variables & Group & N & Mean \pm SD & Sig. \\
\hline Body Weight & Trepca & 5 & $80.91 \pm 9.19$ & \multirow{2}{*}{.645} \\
Body Height & B. Idrizi & 5 & $78.31 \pm 7.89$ & \\
Trepca & 5 & $187.94 \pm 5.13$ & $.029 *$ \\
Length of Arms & B. Idrizi & 5 & $179.72 \pm 4.61$ & \\
Lenght of Hand & Trepca & 5 & $82.16 \pm 3.02$ & \multirow{2}{*}{.477} \\
& B. Idrizi & 5 & $80.71 \pm 3.12$ & \\
Breadth of Hand & Trepca & 5 & $21.64 \pm 1.32$ & \multirow{2}{*}{.247} \\
\hline
\end{tabular}

In table 7 the results between H.C "Prishtina" and H.C presented in favor of H.C "Prishtina", in variables of body „Bashkim Idrizi” are presented. Significant differences are height.

Tabela 7. A T-test between the two groups which are tested in anthropometric spaces

\begin{tabular}{lcccc}
\hline Variables & Group & N & Mean \pm SD & Sig. \\
\hline \multirow{2}{*}{ Body Weight } & Pristina & 5 & $68.89 \pm 6.62$ & \multirow{2}{*}{.076} \\
& B. Idrizi & 5 & $78.31 \pm 7.89$ & \\
Body Height & Pristina & 5 & $187.73 \pm 4.83$ & \multirow{2}{*}{$.028^{*}$} \\
Length of Arms & B. Idrizi & 5 & $179.72 \pm 4.61$ & \\
& Pristina & 5 & $82.31 \pm 1.92$ & \multirow{2}{*}{.359} \\
Lenght of Hand & B. Idrizi & 5 & $80.71 \pm 3.12$ & \\
& Pristina & 5 & $21.16 \pm 1.35$ & \\
Breadth of Hand & B. Idrizi & 5 & $20.60 \pm 1.30$ & .526 \\
& Pristina & 5 & $22.66 \pm 1.94$ & \\
& B. Idrizi & 5 & $22.74 \pm .93$ & .940 \\
\hline
\end{tabular}

\section{Discussion}

The results measured by handball players from four different teams can give us the opportunity to compare stature of handball players, and the average measure of body height of handball players from Kosovo. H.C. Trepça with $187,94 \mathrm{~cm}$ are taller than H.C Prishtina with the average of $187,73 \mathrm{~cm}$, these two teams are taller than players from H.C Kastrioti, with the average body height of $182,83 \mathrm{~cm}$, and H.C Bashkim Idrizi, with $179,72 \mathrm{~cm}$. These teams represent the first four teams of junior handball championship of Kosovo.

In modern handball the average stature is very important. Interestingly, players from H.C Bashkim Idrizi with $179,72 \mathrm{~cm}$ are lower than the player from the first junior league in Serbia with an average body height of $181,51 \mathrm{~cm}$ (Masanovic, Milosevic, \& Corluka, 2018), which has a long tradition in this sport. This fact shows that the players from Kosovo have a good morphological potential. This is no surprise because the Kosovo population is among the highest in the world (Arifi et al., 2017; Arifi, Sermaxhaj, Zejnullahu-Raçi, Alaj, \& Metaj, 2017; Popovic, Gardasevic, Masanovic, Arifi, \& Bjelica, 2017; Masanovic, Gardasevic, \& Arifi, 2018; Gardasevic, Masanovic, \& Arifi, 2018; Arifi, Gardasevic, \& Masanovic, 2018).

Also, in the modern handball game the appropriate body weight is very important. H.C. Trepça with $80.91 \mathrm{~kg}$ and H.C Bashkim with $78.31 \mathrm{~kg}$ have higher body mass than the mentioned Serbian $(74.73 \mathrm{~kg})$ and Norwegian handball players $(76.5 \mathrm{~kg})$ of the same age (Ingebrigtsen, Jeffreys, \& Rodahl,
2013). H.C Kastrioti is just a little bit behind them (73.91) and H.C Pristina players have lower body height than players from Serbian and Norwegian junior league (68.98kg).

To reach the authentication of statistical differences between the four groups, on this occasion we started verification of the differences of "Kastrioti" from Ferizaj which is the first group, in the second group is "Trepca" from Mitrovica, in third group is "Prishtina" from Prishtina, and the fourth in this group is "Bashkim Idrizi" from Gjakova. One of the main importance of this research was to evaluate the anthropometric space and the differences between the four handball teams. During operation, obtained results were treated through descriptive analyses and T-test for independent groups. The main aim of this research has been the anthropometric structure of 4 handball junior teams in Kosovo championship. Analyzing the results achieved by handball players from Kosovo can give us the opportunity to compare some variables with handball players of the same age from other countries who have developed the handball game at a high level. Based on the type of research of this paper we think that theoretical and practical values of this paper are discovering relation between anthropometric space in achieving the high results (Hoppe et al., 2017; Koca, 2009; Vuleta et al., 2006; Ghobadi,H. et.al 2013; Srhoj et al., 2002). The results of this study confirmed the differences between anthropometric variables in anthropometric space to 5 variables, which confirm those morphological characteristics that are presented in important statistical differences. These 
facts show that there are differences from the first-place team to the fourth place in the Kosovo junior championship. Finally, we may say that gained results of this research have realized the main purpose. The results of this scientific paper also confirm the necessity for developing the same models for other handball teams in Kosovo.

Analyzing the results achieved by handball players from Kosovo can give us the opportunity to compare some variables with handball players of the same age from other countries who have developed the handball game at a high level.

\section{Acknowledgements}

There are no acknowledgements.

\section{Conflict of Interest}

The authors declare that there are no conflicts of interest.

Received: 28 December 2018 | Accepted: 20 March 2019 | Published: 19 April 2019

\section{References}

Alaj, I., Arifi, F., Metaj, Z., Cula, L., Nebiu, J., \& Sermaxhaj, S., (2015). Differences In Anthropometric Space And Motor Dimensions Between The Two Clubs In The Category Of Cadets. Sports Mont, 13(2),43-45.

Arifi, F., Bjelica, D., \& Masanovic, B. (2019). Differences in anthropometric characteristics among junior soccer and handball players. Sport Mont, 17(1), 45-49. doi: 10.26773/smj.190208

Arifi, F., Bjelica, D., Sermaxhaj, S., Gardasevic, J., Kezunovic, M., \& Popovic S. (2017). Stature and its Estimation Utilizing Arm Span Measurements in Kosovan Adults: National Survey. International Journal of Morphology, 35(3),1161-1167.

Arifi, F., Gardasevic, J., \& Masanovic, B. (2018). Relationship between foot length measurements and body height: A prospective regional study among adolescents in central region of Kosovo. Sport Mont, 16(3),7579. doi: 10.26773/smj.181013

Arifi, F., Sermaxhaj, S., Alaj, I., Metaj, Z., \& Toverlani, A. (2017). Body Height and Its Estimation Utilizing Arm Span Measurements of both gender Adolescents from Central Region in Kosovo. Sports Mont, 15(2),31-34.

Arifi, F., Sermaxhaj, S., Zejnullahu-Raçi, P., Alaj, I., \& Metaj, Z. (2017). Stature and its estimation utilizing arm span measurements of both gender adolescents from the northern region in Kosovo. Acta Kinesiologica, $11(9), 49-52$.

Bjelica, D., \& Fratrić, F. (2011). Sportski trening: teorija, metodika i dijagnostika. Nikšić: Fakultet za sport i fizičko vaspitanje.

Gardasevic, J., Masanovic, B., \& Arifi, F. (2018). Relationship between tibia length measurements and standing height: A prospective regional study among adolescents in southern region of Kosovo. Sport Mont, 16(3),51-55. doi: 10.26773/smj.181009

Ghobadi, H., Rajabi, H., Farzad, B., Bayati, M., \& Jeffreys, I. (2013). Anthropometry of world-class elite handball players according to the play- ing position: Reports from men's handball world championship 2013. Journal of Human Kinetics, 39(1),213-220.

Gjonbalaj, M., Georgiev, G., \& Bjelica, D. (2018). Differences in Anthropometric Characteristics, Somatotype Components, and Functiona Abilities among Young Elite Kosovo Soccer Players Based on Team Position. Int. J. Morphol., 36(1),41-7.

Hoppe, W.M., Brochhagen, J., Baumgart, Ch., Bauer, J., \& Juergen. (2017). Differences in anthropometric characteristics and physical capacities between junior and adult top-level handball players. Asian Journal Sports Medicine. 8(4),e60663.

Ingebrigtsen, J., Jeffreys, I., \& Rodahl, S. (2013). Physical Characteristics and Abilities of Junior Elite Male and Female Handball Players. Journal of Strength and Conditioning Research, 27(2),302-309.

Koca, A. (2009) Relacionet dhe ndryshimet ne hapeiren antropometrike funksionale dhe aftesive levizore bazike e te levizjeve situacionale ndermjet hendbollisteve (juniore) te superliges dhe liges se pare te kampionatit te kosoves ne hendboll. Disertacion doktorature, Prishtine: Fakulteti i Kultures Fizike.

Marfell-Jones, M., Olds, T., Stew, A.D., \& Carter, J.E.L. (2006). International standards for anthropometric assessment. Potchesfstroom: International Society for the Advancement of Kinanthropometry.

Masanovic, B. (2018). Comparative study of anthropometric measurement and body composition between junior basketball and volleyball players from Serbian national league. Sport Mont, 16(3),19-24. https://doi.org/10.26773/smj.181004

Masanovic, B., Gardasevic, J., \& Arifi, F. (2018). Relationship between foot length measurements and standing height: a prospective regional study among adolescents in southern region of kosovo. Sport Mont, 16(2),27-31. doi: 10.26773/smj.180605

Masanovic, B., Milosevic, Z., \& Corluka, M. (2018). Comparative Study of Anthropometric Measurement and Body Composition between Junior Handball and Volleyball Players from Serbian National League. International Journal of Applied Exercise Physiology, 7(4),1-6. https:// doi.org/10.30472/ijaep.v7i4.313

Popovic, S., Gardasevic, J., Masanovic, B., Arifi, F., \& Bjelica, D. (2017). Standing Height and its Estimation Utilizing Foot Length Measurements in Adolescents from Western Region in Kosovo. Sport Mont, 15(3),3-7.

Saavedra, J.M., Porgeirsson, S., Kristjansdottir, H., Halldorsson, K., Gudmundsdottir, M.L., \& Einarsson, I.P. (2018). Comparison of training volumes in different elite sportspersons according to sex, age, and sport practised. Montenegrin Journal of Sports Science and Medicine, $7(2), 37-42$.

Selimi, M. (2001). Punim Magjistrature Fakulteti i Kultures Fizike, Prishtine, Kosove.

Srhoj, V., Marinovic, M., \& Rogulj,N., (2002). Position specific morpholog ical characteristics of top-level male handball players. Coll. Antropol. 26(1),219-227.

Vuleta, D., Milanovic, D., Gruic, I., \& Jukic, I., (2006). Changes in physical conditioning status of female handball players during the preparation period. In Proceedings book of 3rd International Scientific Conference on Kinesiology, "Kinesiology new perspective" (386-389). Zagreb: Faculty of Kinesiology, University of Zagreb. 